\title{
EL PROCESO VERBAL EN \\ EL CÓDIGO GENERAL DEL PROCESO*
}

\section{The verbal process in the general code process}

\author{
Oscar Iván Garzón Guevara**
}

\begin{abstract}
Resumen
El nuevo proceso verbal surge en el Código General del Proceso a partir de un cambio de paradigma en donde los litigios se resolverán de manera ágil, expedita, con argumentos orales en audiencia, con inmediación y presencia permanente del juez en la práctica de las pruebas, con contacto directo del fallador con las alegaciones de las partes, y con providencias que conviene fijar con atención de carácter eminentemente decisorio que según el Código, implica la posibilidad de ser proferido de manera oral e instantánea, y excepcionalmente escrita cuando no fuere posible dictarla de forma oral, con constancia de las
\end{abstract}

Recebido: 28 de junio de 2016 - Aprobado: 12 de mayo de 2017

* Artículo inédito.

Para citar artículo: GARZÓN, Oscar Iván. El proceso verbal en el Código General del Proceso. Revista del Instituto Colombiano de Derecho Procesal. No. 45 Enero - Junio. 2017, pp. 149-187.

** Abogado de la Universidad Autónoma de Colombia, magíster en Derecho con énfasis en Derecho Procesal de la Universidad Externado de Colombia. Jefe de Programa de la Universidad Cooperativa de Colombia, sede Bogotá. Profesor de pregrado y posgrado en el área de Derecho Procesal y Derecho Privado de las universidades Militar Nueva Granada, Autónoma de Colombia, Manuela Beltrán, Los libertadores y Cooperativa de Colombia. Coordinador de los semilleros de investigación en Derecho Procesal. Abogado litigante, consultor, socio fundador de la firma de abogados Baluarte Jurídico, y miembro del Instituto Colombiano de Derecho Procesal.

Agradecimientos a Laura Estephania Huertas Montero. 
razones concretas, informando al Consejo Superior de la Judicatura y anunciando el sentido del fallo con fundamentos; en oposición a los anteriores trámites surtidos a través de procesos escritos, previstos en el Código de Procedimiento Civil. El propósito de este artículo es hacer una descripción de las normas que regulan los distintos actos procesales y el trámite que debe surtirse en el proceso verbal, con algunos comentarios críticos, con el ánimo de que jueces, abogados y operadores jurídicos en general tengan una noción básica de cómo se solucionarán los conflictos hoy en día, y las diferentes posturas que se podrán asumir en el desarrollo del proceso.

Palabras clave: Proceso verbal, Código General del Proceso, oralidad, audiencias.

\begin{abstract}
The new verbal process arises in the General Code of the Process from a paradigm shift where disputes will be settled agile, expeditious, with oral arguments hearing in an audience, with immediacy and permanent presence of the judge in the practice of evidence, with direct contact of the judge with the arguments of the parties, and with judgments that should be fixed eminently decisive attention that according to the Code, implies the possibility of being pronounced orally and instantaneous, and exceptionally written when it is not possible pronounce it orally, with evidences of the specific reasons, reporting the Supreme Council of the Judiciary and announcing the meaning of the judgment on grounds: as opposed to the past procedures assorted through written processes, provided in the Civil Procedure Code. The purpose of this article is to describe the norms governing the different procedural acts and the procedure that should be done at the verbal process, with some critical comments, with the hope that judges, lawyers and legal practitioners in general they have a basic understanding of how the conflicts will be solved nowadays, and the different positions that will be able to assume in the process development.
\end{abstract}

Key Words: Verbal process, General Code of the Process, orality, audiences.

\title{
Introducción y antecedentes
}

La entrada en vigencia del Código General del Proceso (En adelante CGP) es una fuerte apuesta para mejorar el servicio de justicia en Colombia, que será dispensado por "jueces visibles en juicios orales y por audiencias, con 
inmediación y concentración en las actuaciones procesales" ${ }^{1}$. Es menester señalar que, por el contrario, bajo el Código de Procedimiento Civil (En adelante $\mathrm{CPC}$ ), los procesos civiles eran tendencialmente escritos. El juez y las partes se comunicaban a través de memoriales y autos, y quienes instruían el proceso eran los sustanciadores y los funcionarios de secretaría, y al final el juez debía leer todo el expediente, la demanda, la contestación, las pruebas solicitadas y allegadas por las partes y sus alegatos, para poder emitir el fallo, provocando que los procesos fueran bastante largos.

De esta forma, la nueva codificación procesal será aplicable tanto a los "procesos en curso por el CPC como a los procesos nuevos, con ultractividad excepcional"2. Por eso se modificó el art. 40 de la Ley 153 de 1887 (CGP., art. 624), y se establecieron reglas puntuales de transito de legislación consagradas en el art. 625 del mismo.

En este estatuto procesal existían diferentes procesos declarativos: i) El proceso ordinario, que era el proceso general por medio del cual se sometían todos los asuntos contenciosos de mayor cuantía que no tuvieran un trámite especial; ii) El proceso abreviado, a través del cual se surtían todos los asuntos de menor cuantía; iii) El proceso verbal sumario, a través del cual se surtían todos los procesos de mínima cuantía y algunos otros que sin importar su cuantía, por su propia naturaleza debían ser tramitados por esta cuerda procesal; y iv) Los procesos declarativos especiales.

El legislador con el propósito de implementar la celeridad en los trámites procesales y de introducir en la práctica los principios de inmediación y concentración procesal, -entendidos estos como el agotamiento de varios actos procesales en un solo momento y la promoción del contacto directo que pueda tener el juez con las partes y con los medios de prueba para fallar inmediatamente-, profirió la Ley 1395 de 2010, una Ley de descongestión judicial, que modificó el CPC en lo relativo al trámite de los procedimientos escritos para dar tránsito a la implementación de procesos orales, instruidos principalmente bajo la modalidad de audiencias.

La Ley 1395 suprimió los procesos ordinarios y los procesos abreviados, y estableció que cuando los asuntos fueran de menor y mayor cuantía, se tramitarían por un proceso verbal, y cuando los asuntos fueran de mínima cuantía,

ÁlVAREZ GÓMEZ Marco Antonio, "Ensayos sobre el Código General del Proceso", Bogotá D.C., Colombia, Ed. Temis, Bogotá, 2016.

2 MESTRE ORDOÑEZ José Fernando, ROJAS QUIÑONES Sergio, Revista del Instituto Colombiano de Derecho Procesal, "La oralidad procesal de sus postulados teóricos a su reglamentación adecuada -especial referencia a las recientes reformas legislativas", Bogotá, Revista Virtual No 39, 2013. 
se tramitarían por el proceso verbal sumario, de manera oral y en una sola audiencia.

La Ley 1564 de 2012, que promulgó el CGP, siguiendo la misma línea de la Ley 1395 de implementar la oralidad en los procesos, establece en su art. 3 que las actuaciones deben cumplirse en forma oral, pública y en audiencias, salvo las que expresamente se autorice realizar por escrito o estén amparadas por reserva. Además, consagró el llamado proceso verbal, y en su art. 368 instituyó que por medio de él se tramitarán todos los asuntos contenciosos que no estén sometidos a un trámite especial. Sin embargo, debe entenderse que son asuntos de mayor y menor cuantía, puesto que los asuntos de mínima cuantía se someterán al trámite del proceso verbal sumario, de acuerdo con lo dispuesto en el artículo 390 de este mismo código.

Nos adentramos fundamentalmente el estudio del proceso verbal, recordando el vital entendimiento de los temas desarrollados.

\section{El proceso verbal en el CGP}

El proceso verbal en el CGP está regulado en el libro tercero, desde los arts. 368 a 373, y se concibe como la cuerda procesal general de la cual se nutren y se desprenden los demás procesos del código. Se establece que la mayoría de actos procesales se desarrollarán por el juez de manera oral en audiencia, y que la sentencia se deberá proferir de manera oral en ella, salvo en casos excepcionales en los cuales el fallo podrá proferirse por escrito.

En otros términos, el tramite contemplado en los arts. 369 a 373 del CGP es el que rige específicamente para los procesos verbales de mayor y menor cuantía y para aquellos cuyas pretensiones no permiten realizar una estimación del monto económico de ellas "independientemente de las consecuencias económicas indirectas que pueda generar la sentencia, aspecto que es indiferente para estos fines". ${ }^{3}$

Este proceso se surte en dos fases: i). Una fase escrita, que corresponde al momento en el que se traba la litis, y que incluye la formulación de la demanda, la contestación, y los traslados de las excepciones; y ii). Una fase oral, que comprende el desarrollo de dos audiencias: Una audiencia inicial, prevista en el art. 372 del CGP, en donde se sanea el proceso, se fija el litigio, se intenta la conciliación y se decretan las pruebas, y una audiencia de instrucción y juzgamiento consagrada en el art. 373 del CGP, donde se practican los medios probatorios, se escuchan los alegatos de conclusión de las partes y se dicta fallo.

Ibídem. 


\subsection{Fase escrita}

La fase escrita del proceso verbal inicia con la presentación de una demanda, que deberá seguir los parámetros generales que establece el mismo CGP ${ }^{4}$ :

1. Designación del juez a quien se dirige.

La competencia de los jueces para tramitar este tipo de proceso se determina por las reglas generales y los diferentes factores: cuantía, competencia territorial, fuero subjetivo, previstos en los artículos 15 y ss. del CGP.

2. El nombre y domicilio de las partes, y si no pueden comparecer por sí mismas, los de sus representantes legales.

Cuando se trata de personas naturales, el nombre será el que ellas tengan de acuerdo con sus documentos de identificación, de ahí que no sea posible demandar a una persona citándola solamente por el seudónimo; si se trata de personas jurídicas de derecho público estas deben señalar la nación, departamento, municipio o clase de establecimiento, y para personas jurídicas de derecho privado, se le designará por su razón social de acuerdo con sus estatutos ${ }^{5}$.

3. El nombre del apoderado judicial del demandante.

Eminentemente si se "carece del derecho de postulación, es menester acudir a los servicios de un apoderado judicial"6, quien, por regla general, debe ser abogado profesional, y será este quien deba elaborar la demanda en la cual indicará su nombre.

4. Lo que se pretenda, expresado con precisión y claridad.

También es posible que el demandante acumule en una misma demanda varias pretensiones contra el demandado, aunque no sean conexas, siempre y cuando concurran los siguientes requisitos: i). Que el juez sea competente para conocer de todas ellas, sin tener en cuenta la cuantía; ii). Que las pretensiones no se excluyan entre sí, salvo que se propongan como principales y subsidiarias; y iii). Que todas ellas puedan tramitarse por el mismo proceso verbal, al no tener asignado ningún trámite especial para su resolución? ${ }^{7}$.

4 Colombia, Congreso de la República, Ley 1564 de 2012, "Por medio de la cual se expide el Código General del Proceso", art. 82.

5 LÓPEZ BLANCO, Hernán Fabio, “Código General del Proceso, Parte Especial”, cuarta edición, Bogotá, Ed. Dupre Editores Ltda, 2017.

6 ROJAS GÓMEZ, Miguel, “Lecciones de Derecho Procesal”, Ed. ESAJU, T. 4, Bogotá, 2016. Colombia, Congreso de la República, Ley 1564 de 2012, Por medio de la cual se expide el Código General del Proceso, art. 86. 
5. Los hechos que le sirven de fundamento a las pretensiones, debidamente determinados, clasificados y numerados.

Lo que el legislador le está exigiendo a los apoderados judiciales con esta disposición es que organicen cronológicamente y clasifiquen los hechos jurídicamente relevantes al caso, absteniéndose de redactar versiones $\mathrm{u}$ opiniones subjetivas de los mismos.

6. La petición de los medios probatorios que se quieran hacer valer, con indicación de los documentos que el demandado tiene en su poder para que este los aporte.

7. El juramento estimatorio cuando sea necesario.

El art. 206 del CGP establece que será necesario formular juramento estimatorio cuando se reclamen indemnizaciones de perjuicios patrimoniales, compensaciones o el pago de frutos y mejoras, y se exceptúan de esta exigencia los casos en los cuales se reclame en la demanda perjuicios morales o extrapatrimoniales y cuando quien vaya a reclamar la indemnización, compensación, frutos o mejoras, sea un incapaz.

Sobre este numeral es necesario advertir que se planteó la necesidad de buscar disciplinar a los abogados que de forma irresponsable y precipitada, especialmente en la indemnización de perjuicios, frutos y mejoras, solicitan cifras exageradas, sin base real alguna. A esta práctica le pone fin esta disposición, porque es deber perentorio en las pretensiones de la demanda. ${ }^{8}$

Señalar razonablemente el monto al cual considera que asciende el perjuicio material reclamado, conlleva a estudiar suficientemente y de manera previa a la elaboración de la demanda, las bases económicas del daño sufrido, de manera tal que, si la estimación resulta arbitrariamente exagerada, que para la norma lo viene a construir un exceso de más del $50 \%$, se impondrá la multa equivalente al diez por ciento de la diferencia. ${ }^{9}$

No es necesario allegar o solicitar pruebas para fundamentar el juramento estimatorio porque la aseveración de su monto es la prueba, como tampoco

8 Cfr, LÓPEZ BLANCO, Hernán Fabio, Código General Del Proceso, Parte General, cuarta edición, Bogotá, Ed. Dupre Editores Ltda, año 2016.

9 La Corte Constitucional en la sentencia C-157 de marzo 21 de 2013 decidió con relación al parágrafo del art. 206: "Declarar EXEQUIBLE el parágrafo único del artículo 206 de la Ley 1564 de 2012, por medio de la cual se expide el Código General del Proceso y se dictan otras disposiciones, bajo el entendido de que tal sanción, por falta de demostración de los perjuicios, no procede cuando la causa de la misma sea imputable a hechos o motivos ajenos a la voluntad de la parte, ocurridos a pesar de que su obrar haya sido diligente y esmerado". 
lo es para efectos de la objeción del mismo. Recuérdese que de lo que se trata es dejar de sentado por este medio de prueba las cantidades por las que se puede concretar una condena.

Este requisito no es pertinente en toda demanda, de ahí que la disposición señala que se erige únicamente como tal "cuando sea necesario"10, lo que ocurre en la mayoría de los procesos declarativos y no se da en ningún caso en las demandas ejecutivas pues estas últimas se demanda por cantidad cierta y precisa. Es más, en algunos procesos declarativos tampoco es pertinente cumplir con el requisito si la pretensión se formula por una suma exacta, como sería, por ejemplo, una demanda en contra de una empresa de seguros reclamando el pago de un preciso monto a indemnizar.

El juramento entonces no proviene de la parte sino de la ley, y para que sea estimatorio, en nuestra opinión debe mediar una declaración de la voluntad expresa e inequívoca de la parte que lo hace.

Hay muchos actos que la ley procesal considera prestados bajo la gravedad del juramento, que no tiene el alcance de juramento estimatorio, entre otros, los informes presentados por entidades oficiales prevista en el art. 275 del CGP, en tales casos se trata de un juramento con fines de suplir una prueba o de satisfacer un requisito. ${ }^{11}$

Además, de la única manera que la estimación hecha por el demandante se torna vinculante para las partes y también para el juez, se presenta cuando el demandado no formula objeción alguna en el término del traslado de la demanda, o cuando no las rinde dentro del plazo prudencial que se le señale para ello. En tales casos la cantidad indicada en la demanda, debe acogerse integralmente y sin reservas, porque así lo dispone expresamente la ley.

8. Los fundamentos de derecho.

El CGP en su numeral 8, art. 82, exige que la demanda señale en un aparte los fundamentos de derecho en los cuales apoya las pretensiones de la demanda, es decir, determinar dentro del ordenamiento jurídico las normas en las que se basa el demandante para creer que tiene derecho a que la jurisdicción atienda sus peticiones, de manera que no se trata de una mera ritualidad, sino que atiende a relacionar las normas que considera aplicables al proceso. Sin embargo, si el demandante se equivoca en el derecho aplicable, no se podría tomar esta hipótesis como una excusa para inadmitir la demanda o denegar el derecho al acceso a la administración de justicia, pues se presume

10 LÓPEZ BLANCO, Hernán Fabio, Ley 1395 de 2010, Reformas al Código de Procedimiento Civil, Dupre Editores, Bogotá, 2010.

11 Cfr., BEJARANO GUZMÁN, Ramiro, Procesos declarativos, arbitrales y ejecutivos, Editorial Temis S.A., Bogotá 2016. 
que el juez conoce del derecho (iura novit curia) y que en todo caso deberá fallar aplicando al caso las normas correctas.

9. La cuantía del proceso, cuando su estimación sea necesaria para determinar la competencia o el trámite.

En los procesos en que la competencia se determine por el valor de las pretensiones, es necesario establecer si se trata de un proceso de mínima, menor o de mayor cuantía, con el objeto de que ello sirva de base para saber si la demanda está dirigida al juez competente para conocer el asunto.

10. El lugar, la dirección física y electrónica que tengan o estén obligados a llevar, donde las partes, sus representantes y el apoderado del demandante recibirán notificaciones personales. Esta disposición es nueva respecto del anterior Código de Procedimiento Civil, que sólo consideraba las direcciones físicas de notificación.

Las notificaciones contribuyen a materializar una de las reglas orientadoras del sistema procesal, como es el principio de publicidad, es decir que las providencias emitidas por el juez, deben ser comunicadas a las partes o sus apoderados, para que conocidas por estos puedan hacer uso de los derechos que la ley consagra para impugnarlas, aclararlas, complementarlas o, simplemente, para que enteradas de su contenido, se dispongan a cumplir lo allí ordenado.

Notificar significa hacer saber, hacer conocer y el sentido que toma la ciencia procesal el vocablo, es el medio con el que se "quiere comunicar a las partes y terceros autorizados para intervenir en el proceso las providencias judiciales que dentro de él se profieren"12.

Es tal su importancia, que el inciso segundo del art. 289 del CGP, dispone que "Salvo los casos expresamente exceptuados, ninguna providencia producirá efectos antes de haberse notificado", directriz que cumple un papel central en el desarrollo del derecho fundamental al debido proceso, pues impide que se puedan hacer efectivas decisiones judiciales sin dar la oportunidad previa de su controversia.

La normas del CGP que se refieren a la notificación personal ${ }^{13} \mathrm{y}$ a la notificación por aviso ${ }^{14}$ a través de correo electrónico, afirman que se presume

12 DEVIS HECHANDIA, Hernando, Estudios de Derecho Procesal, Bogotá, Ed. ABC, 1979.

13 Colombia, Congreso de la República, Ley 1564 de 2012, Por medio de la cual se expide el Código General del Proceso, art. 291.

14 Colombia, Congreso de la República, Ley 1564 de 2012, Por medio de la cual se expide el Código General del Proceso, art. 292. 
que el destinatario ha recibido la comunicación o el aviso cuando el iniciador recepcione acuse de recibo, y en estos casos, deberá dejarse constancia de esto en el expediente y adjuntar una impresión del mensaje de datos. Para el caso de la notificación personal, a partir de la recepción del correo por el destinatario, este tendrá el término previsto en el art. 291 del CGP para comparecer al juzgado; y en el caso de la notificación por aviso, el art. 292 del CGP establece que el destinatario del correo electrónico, una vez se ha acusado recibo del mismo, se entendería notificado al finalizar el día siguiente a esa fecha.

El art. 20 de la Ley 527 de 1999, que regula los mensajes de datos y el comercio electrónico, establece que si al enviar o antes de enviar un mensaje de datos, el iniciador solicita o acuerda con el destinatario que se acuse recibo del mensaje de datos, pero no se ha acordado entre ellos una forma o método determinado para efectuarlo, se podrá acusar recibo mediante: i). Toda comunicación del destinatario, automatizada o no, o ii). Todo acto del destinatario que baste para indicar al iniciador que se ha recibido el mensaje de datos ${ }^{15}$. En el mismo sentido, el art. 21 de esta misma ley consagra que cuando el iniciador recepcione acuso de recibo del destinatario, se presume que este ha recibido el mensaje de datos ${ }^{16}$. Se ha definido al iniciador del mensaje de datos como aquella persona que por su cuenta o en cuyo nombre se haya actuado, genera, crea o envía el documento, mensaje, o correo electrónico ${ }^{17}$.

Bajo estas consideraciones, se deberán configurar los correos de los juzgados ${ }^{18}$ y de las partes para que, una vez enviada la comunicación para la

15 Colombia, Congreso de la República, Ley 527 de 1999, literales a) y b), inciso 1, art. 20. Colombia, Congreso de la República, Ley 527 de 1999, inciso 1, art. 21.

17 Numeral 2, Art. 3, Decreto 333 de 2014. En el mismo sentido, la doctrina se ha pronunciado afirmando que el iniciador de un mensaje de datos o de un correo electrónico es aquél que crea el documento o el mensaje. Cfr. FLÓREZ, Germán Darío, "La validez jurídica de los documentos electrónicos en Colombia a partir de su evolución legislativa y jurisprudencial", Revista Verba Iuris No. 31, enero-Junio de 2014, Bogotá, pp. 43-71. Disponible en: http://www.unilibre.edu.co/verbaiuris/31/la-validez-juridica-de-los-documentoselectronicos-en-colombia-a-partir-de-su-evolucion-legislativa-y-jurisprudencial.pdf, fecha de consulta: 17 de junio de 2016.

18 Así, por ejemplo, en Bogotá, hay varios juzgados como el 45 civil del circuito que ya poseen un correo oficial y realiza comunicaciones y notificaciones a través de él. El acuso de recibo que da ese despacho consiste en un mensaje automatizado de respuesta a todo correo que se reciba, el que no se supedita a que el mensaje haya sido abierto y leído, sino únicamente a que efectivamente haya sido recibido en la cuenta oficial. Cuando envían una comunicación o una notificación solicitan acuso de recibo, el que puede darse por cualquier medio, pues la ley no indica cuál es el método 
notificación personal o el aviso a la persona que debe ser notificada, se pida confirmación de recibo, y una vez se reciba dicha confirmación, esta pueda ser impresa junto con el correo para dejar constancia en el expediente y que se puedan producir los respectivos efectos procesales, independientemente de si se abrió por error o no el correo electrónico.

En caso de que el correo electrónico rebote, deberá usarse por el interesado la dirección física de notificaciones del demandado y enviar la comunicación o el aviso a través de servicio postal autorizado, puesto que, de acuerdo con el art. 82 del CGP, es forzoso que el demandante indique la dirección física y electrónica del demandado. En caso de que se manifieste que no se conoce la dirección de notificaciones del demandado, se deberá proceder a la notificación por emplazamiento, de la forma prevista en el $\mathrm{CGP}^{19}$. Actualmente, será necesario que se indique expresamente que no se conoce ni la dirección física ni la dirección electrónica de notificaciones del demandado, so pena de inadmisión de la demanda.

11. Los demás requisitos que la ley señale que deban ser incluidos en la demanda.

para tal verificación, lo que incluye un mensaje de datos emitido por el proveedor del servicio de correo del destinatario, un mensaje automatizado de recepción del correo, un mensaje personalizado $\mathrm{u}$ otros medios, aún distintos a mensajes de datos, tales como confirmación telefónica o escrita. Los archivos adjuntos son tratados de acuerdo con la ley que rige el determinado caso, en los términos de la Ley 527 de 1999 y en especial el art. 625 del Código General del Proceso. De otra parte, en juzgados como el 25 civil del circuito, aunque este despacho también posee un correo electrónico oficial, las notificaciones por correo electrónico solo se han implementado en las acciones de tutela, y la función actual del correo se limita únicamente a intercambiar comunicaciones o informaciones con otras dependencias judiciales o administrativas de la judicatura. Además, tampoco cuentan con un método para verificar el acuse de recibo de los correos y notificaciones. Fuente: preguntas vía correo electrónico a los miembros de dichos despachos judiciales.

19 Parágrafo primero, art. 82, arts. 293 y 108 del CGP. La novedad de la notificación por emplazamiento respecto al anterior Código de Procedimiento Civil, está en que, además de incluir a la persona emplazada, la clase de proceso, las partes que intervienen y el juzgado que lo requiere, en el listado que se publicará por una sola vez en un periódico de amplia circulación nacional, es necesario que la parte interesada en la notificación remita una comunicación al Registro Nacional de Personas Emplazadas, que es una base de datos que lleva el Consejo Superior de la Judicatura, incluyendo el nombre del sujeto emplazado, su número de identificación si se conoce, las partes del proceso, la naturaleza del proceso, y el juzgado que lo requiere. Una vez se haya publicado la información en dicho registro, la notificación por emplazamiento se entenderá surtida a los 15 días siguientes. 
Además de estos requisitos formales, el art. 84 del CGP prescribe una serie de anexos obligatorios que debe contener la demanda:

a. El poder para iniciar el proceso, cuando se actúe por medio de apoderado.

Bien es sabido que puede constituirse el apoderado mediante dos sistemas previstos en el art. 74 del CGP que dispone: "Los poderes generales para toda clase de procesos solo podrán conferirse por escritura pública. El poder especial para uno o varios procesos podrá conferirse por documento privado. En los poderes especiales los asuntos "deberán estar determinados y claramente identificados", con los cuales se determina que si se trata de poder general únicamente se puede mediante escritura pública, pues si se trata de poderes especiales para uno o varios procesos debidamente especificados basta el escrito privado que requiere de presentación personal, es decir autenticación. Este documento es uno de los pocos documentos privados en los que se exige la formalidad de la autenticación cuando se confiere por escrito, debido a que respecto a ellos no rige la presunción de autenticidad prevista en el art. 244 del CGP, inciso tercero: “También se presumirán auténticos los memoriales presentados para que formen parte del expediente, incluidas las demandas, sus contestaciones, los que impliquen disposición del derecho en litigio y los poderes en caso de sustitución", de modo que respecto a los poderes tan solo para las sustituciones del poder es que se presume su autenticidad.

Formalidades como la presentación personal es para el poderdante no para el abogado. Esto, debido a una infortunada interpretación de la Corte Suprema de Justicia ${ }^{20}$, bajo la cual se recomienda por razones prácticas que el abogado, al aceptar el poder, lo que es usual hacerlo en el mismo escrito al suscribirlo en señal de aceptación, autentique su firma, cuidándose de que se tome nota de la existencia de su tarjeta profesional.

La Corte, basada en el art. 22 del decreto 196 de 1971 que prescribe: "Quien actúe como abogado deberá exhibir su tarjeta profesional al iniciar la gestión, de lo cual se dejará testimonio escrito en el respectivo expediente. Además, el abogado que obre como tal, deberá indicar en todo memorial el número de su tarjeta. Sin el cumplimiento de estas formalidades no se dará curso a la solicitud", afirmó que "para poder asumir válidamente la defensa de la parte a quien se dice apoderar, ineludiblemente el abogado, al iniciar su gestión, debe acreditar esa calidad, para de esa manera tener plenamente satisfecho el derecho de postulación" ${ }^{21}$.

20 Colombia, Corte Suprema de Justicia, auto de junio 3 de 1990, Magistrado Ponente: José Fernando Ramírez, expediente 7657.

21 Lo más criticable de la decisión de la Corte fue que inadmitió el recurso extraordinario de casación interpuesto por un abogado que al hacerlo no había exhibido la tarjeta profe- 
Olvidó la Corte que los abogados preponderadamente actúan a través de documentos denominados memoriales y que estos, salvo excepciones expresas, están dotados de la presunción de autenticidad, aspecto que ligado a la buena fe que se presume de todas las actividades de los particulares ante las autoridades públicas como son los jueces, permiten aceptar que, sin formalidad especial, se admita que quien se anuncia como abogado y cita el número de la tarjeta que lo acredita, no deba cumplir con otra formalidad para ser escuchado ${ }^{22}$, pues el art. 83 de la Constitución Política, representa un cambio esencial al destacar que la buena fe "se presumirá en todas las gestiones que aquellos (los particulares) adelantan ante estas (las autoridades públicas)", de modo que al enunciarse como abogado y señalar el número de tarjeta profesional, se deba de creer y proceder en el estudio de reconocerle personería jurídica.

b. La prueba de la existencia y representación de las partes y de la calidad en la que intervendrán en el proceso, teniendo en cuenta los parámetros establecidos en el art. 85 de este mismo código.

c. Las pruebas extraprocesales y los documentos que se pretenda hacer valer y se encuentren en poder del demandante.

d. Los demás que la ley exija.

La demanda debe radicarse, sin necesidad de presentación personal, ante el secretario del respectivo despacho judicial al que se dirija o ante la oficina judicial de reparto, quien dejará constancia de la fecha de su recepción. Con la demanda debe acompañarse copia para el archivo del juzgado, y tantas copias de ella y de sus anexos cuantas sean las personas a quienes deba correrse traslado ${ }^{23}$. La fecha de presentación de la demanda se hace importante, pues ella determina en qué momento se interrumpe la prescripción o se hace inoperante la caducidad, si se cumplen con los requisitos del art. 94 del CGP.

Además, deberá adjuntarse la demanda como mensaje de datos junto con sus pruebas y anexos (en CD) para el archivo del juzgado y el traslado de los demandados. Si se ha habilitado el plan de justicia digital, en dicho lugar no será

sional quien, no obstante, presento su tarjeta después de sustentada la casación y antes de que se inadmitiera el recurso, con el argumento de que "no se puede sostener que una vez cumplida la formalidad sus efectos se extiendan hacia el pasado, no solo porque las actuaciones judiciales no puedan quedar al capricho de las partes, sino porque ello desconocería el principio procesal de la preclusión.

22 Cfr, ROJAS GÓMEZ, Miguel Enrique, Código General del Proceso Comentado, Ed. ESAJU, Bogotá, 2012.

23 Incisos 1 y 2 (parcial), art. 89, CGP. 
necesario presentar copia física de la demanda ${ }^{24}$. Las demandas que se presenten en mensaje de datos no requerirán de la firma digital definida en la Ley 527 de 1999, sino que en estos casos bastará con que el suscriptor se identifique con su nombre y documento de identificación en el mensaje de datos ${ }^{25}$.

Una vez es recibida la demanda en el despacho del juez, este último deberá verificar si la demanda reúne todos los requisitos de ley, y deberá decidir una de tres $\cos ^{26}{ }^{26}$ :

1. Admitir la demanda: En este caso, si el juez encuentra que la demanda cumple con todos los requisitos y anexos de ley, la admitirá y le dará el trámite que legalmente le corresponda, aunque el demandante haya indicado una vía procesal inadecuada.

2. Inadmitir la demanda: El juez podrá inadmitir la demanda cuando:

a. No reúna los requisitos formales. Dados los cambios sustanciales del CGP para adaptarse a las nuevas tecnologías al servicio de los procesos judiciales, se puede afirmar que los juzgados podrán inadmitir las demandas si no se incluye en el escrito de demanda la dirección electrónica de notificaciones del demandado. En esta hipótesis, para evitar la inadmisión de la demanda, se deberá manifestar expresamente en ella que no se conoce la dirección electrónica y/o física del demandado.

b. No se acompañen los anexos ordenados por la ley. Los juzgados también podrán inadmitir las demandas si no se allega copia de la demanda en CD para el archivo del juzgado y para los traslados.

c. Las pretensiones acumuladas no reúnan los requisitos legales.

d. El demandante sea incapaz y no actúe por conducto de su representante.

e. Quien formule la demanda carezca de derecho de postulación para adelantar el respectivo proceso.

f. No contenga el juramento estimatorio siendo necesario.

g. Cuando no se acredite que se agotó la conciliación extrajudicial como requisito de procedibilidad. En este supuesto, en el caso de los procesos verbales siempre será necesario agotar la conciliación como requisito de

$24 \quad$ Inciso 2 (parcial), art. 89, CGP.

25 Parágrafo segundo, art. 82, CGP. Además, es necesario resaltar en relación con la firma electrónica que el artículo 7 de la Ley 527 de 1999, que fue reglamentado por el Decreto Nacional 2364 de 2012, afirma que este requisito se entenderá surtido si por cualquier medio se puede identificar al iniciador del mensaje de datos, sin que sea obligatorio crear la firma a través de las entidades de certificación digital.

Art. 90, CGP. 
procedibilidad, salvo que se demande o sea obligatoria la citación de indeterminados, se desconozca el paradero del demandado, o se solicite la práctica de medidas cautelares ${ }^{27}$.

La inadmisión de la demanda es la posposición de la admisión del escrito inicial, que el juez debe declarar de oficio y mediante auto que no admite ningún recurso, cuando encuentra alguna de las situaciones taxativamente contempladas en los numerales 1 a 7 del art. 90 del CGP, las que se refieren a circunstancias de forma mas no de fondo.

Para inadmitir una demanda el juez debe proferir un auto motivado que específicamente señale los "defectos que se encuentra en ella con el fin que el demandante lo subsane dentro el término de cinco días hábiles, so pena de que no se subsane dentro del término se rechace la demanda" ${ }^{28}$.

Es deber del juez, señalar concretamente cuales son los requisitos que no se cumplieron, porque él a diferencia del legislador, decide para el caso en específico y es su obligación precisar exactamente cuál es la falla o fallas que deben ser subsanadas y no mencionar en abstracto que las encuentra, errada forma de decisión que debe ser proscrita de nuestros estrados judiciales.

Cabe advertir que las posibilidades de inadmisión de la demanda se predican de idéntica manera del escrito de reforma o adición de la demanda, de ahí que una vez presentado el mismo como el juez debe pronunciarse acerca de su inadmisibilidad o no, bien puede acontecer que encuentre alguna falla la cual ordenara corregir dentro el plazo de los cinco días siguientes so pena de rechazo de escrito de corrección o adición, advirtiendo desde ahora que igualmente goza de la facultad para rechazar in límite el escrito de corrección de la demanda por las causales que le hubieran permitido hacerlo respecto del inicial, hipótesis en las cuales queda incólume la inicial demanda.

3. Rechazar la demanda: El juez únicamente puede rechazar la demanda cuando carezca de jurisdicción o de competencia, o haya caducado la respectiva

27 Inciso 1, art. 38, Ley 640 de 2001, modificado por el artículo 621, CGP: "Si la materia de que se trate es conciliable, la conciliación extrajudicial en derecho como requisito de procedibilidad deberá intentarse antes de acudir a la especialidad jurisdiccional civil en los procesos declarativos, con excepción de los divisorios, los de expropiación y aquéllos en los que se demande o sea obligatoria la citación de indeterminados"; y parágrafo 1, Art. 590, CGP: "En todo proceso y ante cualquier jurisdicción, cuando se solicite la práctica de medidas cautelares se podrá acudir directamente al juez, sin necesidad de agotar la conciliación prejudicial como requisito de procedibilidad". Cfr. En el mismo sentido: BEJARANO GUZMÁN, Ramiro, Procesos declarativos, arbitrales y ejecutivos, Sexta Edición, Bogotá, Ed. Temis, año 2016, pp. 10-12.

28 LÓPEZ BLANCO, Hernán Fabio, Normas vigentes de la Ley 1564 de 2012, Dupre Editores, Bogotá, 2013. 
acción. En los casos de rechazo por falta de competencia o de jurisdicción, el fallador ordenará enviar la demanda junto con sus anexos al juez que considere competente; y en el caso del rechazo por caducidad, ordenará devolver los anexos de la demanda sin necesidad de desglose.

El auto que rechace la demanda es susceptible del recurso de reposición y de apelación. El recurso de alzada, se concederá en el efecto suspensivo y se resolverá de plano, toda vez que aún no se encuentra trabada la litis, y, por lo tanto, no se requiere correr traslado a la contraparte.

Si se admite la demanda conforme a los parámetros descritos en los párrafos anteriores, el auto admisorio se deberá notificar por estado al demandante y personalmente al demandado ${ }^{29}$, y en él se ordenará el traslado de la demanda al demandado por un término de 20 días $^{30}$. El traslado de la demanda se surtirá mediante su entrega, en medio físico o como mensaje de datos (CD), de copia de la demanda y sus anexos al demandado, a su representante o apoderado, o al curador ad litem. Si la notificación del auto admisorio de la demanda se surtió por conducta concluyente, por aviso o mediante comisionado, el demandado podrá solicitar en la secretaría que se le suministre la reproducción de la demanda y de sus anexos dentro de los 3 días siguientes, vencidos los cuales comenzará a correr el término de ejecutoria y de traslado de la demanda ${ }^{31}$.

En el término de traslado, el demandado podrá contestar la demanda formulando excepciones de mérito, demandar en reconvención, llamar en garantía o algún tercero, allanarse a la demanda, y proponer excepciones previas.

\section{Allanamiento a la demanda:}

En este caso, el demandado se puede pronunciar aceptando expresamente los hechos y pretensiones de la demanda, es decir, reconociendo sus fundamentos de hecho, y en esta hipótesis, el juez deberá dictar sentencia a favor del demandante, salvo que decrete pruebas de oficio por advertir posible colusión o fraude, "lo cual implica disponer de los poderes disciplinarios y correccionales que se le confieren por mandato legal." $32 \mathrm{Si}$ el allanamiento no se refiere a la totalidad de las pretensiones de la demanda o no proviene de

29 Colombia, Congreso de la República, Ley 1564 de 2012, Por medio de la cual se expide el Código General del Proceso, art. 296.

30 Colombia, Congreso de la República, Ley 1564 de 2012, Por medio de la cual se expide el Código General del Proceso, art. 369.

31 Colombia, Congreso de la República, Ley 1564 de 2012, Por medio de la cual se expide el Código General del Proceso, incisos 1 y 2, art. 91.

32 BEJARANO GUZMÁN, Ramiro, Procesos declarativos, arbitrales y ejecutivos, Sexta Edición, Bogotá, Ed. Temis, 2016. 
todos los demandados, el juez deberá proferir sentencia parcial y el proceso deberá continuar su curso respecto de las pretensiones no allanadas y/o de los demandados que no se allanaron ${ }^{33}$.

El demandado puede asumir esta conducta no solo dentro del término de traslado de la demanda sino también hasta antes de la sentencia de primera instancia, puesto que si se profiere el fallo y el demandado quiere acogerse a lo dispuesto en él, el camino ya no será el del allanamiento a la demanda sino el de cumplir las disposiciones contenidas en la sentencia ${ }^{34}$.

\section{Contestación de la demanda formulando excepciones de mérito:}

De acuerdo con el art. 96 del CGP, la contestación de la demanda deberá contener:

a. El nombre del demandado, su domicilio y los de su representante y apoderado en caso de no comparecer por sí mismo, el número de documento de identificación del demandado y el de su representante; y en tratándose de personas jurídicas y patrimonios autónomos, deberá indicarse el número de identificación tributaria (NIT).

b. Un pronunciamiento expreso y concreto sobre las pretensiones y los hechos de la demanda, con indicación de los que se admiten, los que se niegan y los que no le constan, y en estos dos últimos casos el demandado deberá manifestar de manera precisa y unívoca las razones de su respuesta, so pena de que se presuma como cierto el respectivo hecho que admita confesión.

c. Las excepciones de mérito que se quieran proponer contra las pretensiones de la demanda, con expresión de su fundamento fáctico, el juramento estimatorio (si fuera necesario para pedir compensación o mejoras, por ejemplo), y la alegación del derecho de retención si fuere el caso. Si es necesario en el respectivo caso realizar juramento estimatorio por parte del demandado, y este no cumple con esta carga procesal, el juez le hará un requerimiento para que lo realice, y una vez vencido este término sin que el demandado cumpla, la falta de juramento estimatorio impedirá que sea considerada la respectiva reclamación del demandado ${ }^{35}$.

Las excepciones de mérito se han definido por la doctrina como la alegación de circunstancias de hecho que tienen como propósito enervar la pretensión del demandante, y por esta razón no tienen un nomen iuris propio en la ley,

33 Incisos 1 y último, art. 98, CGP.

34 Cfr. BEJARANO GUZMÁN, Ramiro, op. cit, p. 25.

35 Colombia, Congreso de la República, Ley 1564 de 2012, Por medio de la cual se expide el Código General del Proceso, art. 97. 
no hay una lista taxativa de ellas y para proponerlas no es necesario asignarles rótulo ${ }^{36}$.

De ellas se correrá traslado al demandante por 5 días por fijación en lista y sin necesidad de auto que lo ordene, para que este pida pruebas adicionales sobre los hechos en que ellas se fundan ${ }^{37}$, y estas excepciones se resuelven por el juez en la sentencia.

d. La petición de pruebas que el demandado pretenda hacer valer, sino obran en el expediente.

e. El lugar, la dirección física y de correo electrónico que tengan o estén obligados a llevar, donde el demandado, su representante legal o apoderado recibirán notificaciones personales.

La contestación de la demanda no es obligatoria para el demandado, pero constituye un valioso instrumento que la ley otorga para el adecuado ejercicio de su derecho de contradicción, ya que podrá encauzar su defensa mediante ese escrito. El juez está obligado a pronunciarse sobre si admite o no la respuesta, verificando todos los escritos de la contestación. Si el juzgador rechaza la contestación de la demanda, este auto será apelable conforme al numeral 1 del art. 321 del CGP.

A la contestación de la demanda deberá acompañarse el poder, la prueba de la existencia y representación del demandado, si a ello hubiere lugar, los documentos que se encuentren en su poder y que hayan sido solicitados por el demandante o la manifestación de que no los tiene, y las pruebas que pretende hacer valer dentro del proceso.

Si el demandado no contesta la demanda, o no se pronuncia de manera expresa respecto de los hechos y pretensiones de la misma, indicando por qué los niega y/o por qué no le constan, estas conductas harán presumir ciertos los hechos susceptibles de confesión contenidos en la demanda ${ }^{38}$.

\section{Llamar en garantía o vincular a algún tercero:}

En este caso el demandado en el escrito de contestación de la demanda o en uno separado podrá solicitar la intervención de un tercero, como por ejemplo un llamado en garantía o la vinculación del verdadero tenedor o poseedor.

En el caso del llamamiento en garantía, a la demanda inicial deberá acompañarse la demanda donde se llama en garantía al tercero, y el secretario

36 Cfr. ROJAS GÓMEZ, Miguel Enrique, El proceso civil colombiano, cuarta edición, Bogotá, Ed. Universidad Externado de Colombia, 2011, p. 196.

37 Art. 370, CGP.

38 Colombia, Congreso de la República, Ley 1564 de 2012, Por medio de la cual se expide el Código General del Proceso, inciso 1, art. 97. 
pasará el expediente al despacho para que se decida si se admite o no esta vinculación. Si se admite, se ordenará la notificación personal del llamado y correrle traslado de la demanda de llamamiento por el mismo término de la demanda inicial. Si la notificación no se logra dentro de los 6 meses, esta vinculación será ineficaz $^{39}$.

El llamado en garantía podrá contestar en un solo escrito la demanda inicial y el llamamiento, y solicitar las pruebas que pretenda hacer valer. Se ha afirmado por la doctrina que el traslado al demandante de las excepciones de mérito que realiza el demandado dependerá de si el llamado fue oportunamente citado, compareció al proceso y también excepcionó de fondo. En este sentido, si el llamado en garantía contesta la demanda y formula excepciones de mérito, se correrá traslado simultánea y conjuntamente de estas y de las propuestas por el demandado al demandante para que pida pruebas adicionales, pero si por el contrario, transcurrió el término de los 6 meses sin que se haya efectuado la notificación del llamado, deberá correrse el traslado normal de los 5 días para que el demandante se pronuncie sobre las excepciones de mérito formuladas por el demandado ${ }^{40}$.

Todo lo anterior sucede de igual manera cuando el demandado, dentro del término de traslado de la demanda, solicita la vinculación del verdadero tenedor o poseedor, en los términos del art. 67 del CGP ${ }^{41}$.

\section{Proposición de excepciones previas:}

Para el caso de las excepciones previas, se afirma por los artículos 100 y 101 del CGP que el demandado las puede proponer dentro del término de traslado de la demanda, para sanear aspectos formales del proceso, pero sin que se le imponga la carga de contestar la demanda ${ }^{42}$. Se establecen además, causales taxativas por las cuales el demandado podrá interponer excepciones previas, y se afirma que aquellas se deben formular en escrito separado al de la contestación de la demanda, acompañado de todas las pruebas ${ }^{43}$ que se pretendan hacer valer y que se encuentren en poder del demandado.

39 Colombia, Congreso de la República, Ley 1564 de 2012, Por medio de la cual se expide el Código General del Proceso, arts. 65 y 66.

40 BEJARANO GUZMÁN Ramiro, "Procesos declarativos, arbitrales y ejecutivos", Sexta Edición, Bogotá D.C, Colombia, Ed. Temis, 2016.

41 Cfr. BEJARANO GUZMÁN, Ramiro, op. cit, p. 27.

42 Cfr. Ibídem.

43 Aunque de la lectura literal de esta disposición podría entenderse que es válido para el demandado presentar cualquier medio probatorio para sustentar las excepciones previas y lograr un estado de convencimiento en el juez sobre este punto, existen doctrinantes 
Es necesario en este punto hacer alusión a las excepciones mixtas que existían bajo el régimen del Código de Procedimiento Civil, y que fueron introducidas por la Ley 1395 de 2010. Este régimen le daba la posibilidad al demandado de interponer las excepciones como previas en escrito separado, aun cuando en su esencia fueran excepciones de mérito, para que fueran resueltas por el juez en sentencia anticipada y no al final del proceso. Estas excepciones eran la transacción, la caducidad, la cosa juzgada, prescripción extintiva y falta de legitimación en la causa. Sin embargo, el art. 100 del CGP eliminó esta posibilidad y estas excepciones tendrán que proponerse ahora como lo que son: como excepciones de mérito, dentro del escrito de contestación de la demanda. Sin embargo, se deja a salvo la posibilidad de que cuando se encuentre probada la cosa juzgada, la transacción, la caducidad, la prescripción extintiva y la carencia de legitimación en la causa, el juez las pueda declarar probadas en sentencia anticipada ${ }^{44}$.

Ante esto, surge una situación particular con la excepción de prescripción extintiva. El art. 282 del CGP establece expresamente que la excepción de prescripción extintiva debe ser obligatoriamente propuesta en la contestación de la demanda, pues si no se interpone oportunamente se entenderá renunciada por el demandado.

Así entonces, en caso de que excepciones como la transacción, la caducidad, la cosa juzgada, y la ausencia de legitimación en la causa se aleguen fuera del término para contestar la demanda, si se alegan con posterioridad y el juez encuentra que están probadas, igualmente podría dictar sentencia anticipada para declararlas, bajo el amparo del art. 278 del CGP. Pero, en el caso de la prescripción extintiva, aun cuando la encuentre probada, sólo podrá reconocerla si se alegó a tiempo, es decir, dentro del escrito de contestación de la demanda.

Del escrito que contenga las excepciones previas se dará traslado al demandante por tres días a través de fijación en lista, de conformidad al art. 110 del CGP, para que se pronuncie sobre ellas y si fuere el caso, subsane los defectos formales anotados ${ }^{45}$. Luego de surtido este traslado, el juez decidirá sobre las excepciones previas que no requieren práctica de pruebas adicionales a las que ya se encuentran en el expediente, y si se requiere práctica de pruebas,

que consideran que, aun con el CGP, las únicas pruebas conducentes e idóneas para sustentar las excepciones previas, son las documentales. Cfr. Ibídem.

44 Colombia, Congreso de la República, Ley 1564 de 2012, Por medio de la cual se expide el Código General del Proceso, numeral 3, inciso último, art. 278.

45 Colombia, Congreso de la República, Ley 1564 de 2012, Por medio de la cual se expide el Código General del Proceso, numeral 1, inciso 3, art. 101. 
las decretará, y las practicará y resolverá las excepciones en la audiencia inicial ${ }^{46}$. En todo caso, el juez se deberá abstener de decretar pruebas de otra clase, salvo cuando se alegue falta de competencia por el domicilio de persona natural o por el lugar donde ocurrieron los hechos, o la falta de integración del litisconsorcio necesario, caso en el cual el juez podrá decretar la práctica de hasta dos testimonios ${ }^{47}$. El auto que decide las excepciones previas no es susceptible de apelación, pero sí lo será de reposición.

Respecto a la norma anteriormente mencionada, ¿a qué se refiere la prohibición para el juez de decretar pruebas "de otra clase" para resolver las excepciones previas?, ¿Se refiere a la prohibición de decretar pruebas distintas a las documentales?, o ¿se refiere a decretar pruebas distintas a las allegadas con el escrito? Si es esto último, esta disposición entraría en contradicción manifiesta con la norma que permite al demandado allegar cualquier medio probatorio con el escrito que sustenta sus excepciones previas.

\section{Demanda en reconvención:}

El art. 371 del CGP también permite que el demandado, dentro del término de traslado de la demanda, demande en reconvención o contrademande a la parte demandante, siempre que se cumplan los siguientes requisitos:

a. Que dicha reconvención se dirija contra la parte demandante. Si se afirma que la reconvención constituye un caso de acumulación de acciones ${ }^{48}$, sólo puede contrademandarse a aquella parte que ha formulado líbelo, y la única forma en la que resultaría viable la hipótesis de demandar en reconvención a quien inicialmente no haya tenido la calidad de demandante, es cuando el demandado, además de reconvenir a aquella parte, solicita que se vincule a un

46 Colombia, Congreso de la República, Ley 1564 de 2012, Por medio de la cual se expide el Código General del Proceso, numeral 2, Inciso 3, art. 101.

47 Colombia, Congreso de la República, Ley 1564 de 2012, Por medio de la cual se expide el Código General del Proceso, inciso 2, art. 101.

48 Autores como el Dr. Bejarano, postura con la que estamos de acuerdo, afirman que la reconvención configura una hipótesis de acumulación de acciones, en la medida en que las dos demandas se llevan de forma paralela y sólo puede demandarse a quién fue demandante inicialmente. Sin embargo, autores como el profesor Jairo Parra Quijano consideran por el contrario que lo que la reconvención produce es un fenómeno de acumulación de pretensiones, y que en este sentido se puede reconvenir a sujetos que no sean demandantes, a los cuales el auto que admite la reconvención deberá notificárseles personalmente y no por estado. Estamos de acuerdo con la primera postura presentada, en la medida en que se compagina con el tenor literal de la norma, donde se afirma que la demanda de reconvención se propone contra el demandante. En: Cfr. BEJARANO GUZMÁN Ramiro, op. cit., p. 28. 
tercero como litisconsorte necesario de la parte actora, o cuando prospera la excepción previa en ese sentido. Esta hipótesis sería posible en la medida en que el tercero adquiriría la calidad de parte demandada como litisconsorte necesario ${ }^{49}$.

Dentro de este requisito se plantea también por la doctrina la posibilidad de que, si son varios los sujetos que integran la parte demandante y/o demandada, no será necesario que el demandado formule reconvención contra todos los demandantes, sino que podrá reconvenir a uno, a alguno o a todos; y en el mismo sentido, tampoco será necesario que todos los demandados formulen reconvención, sino que podrá realizarla uno, algunos o todos ellos. Sin embargo, si existe litisconsorcio necesario en cualquiera de los extremos de la relación procesal, la reconvención deberá ajustarse a esta situación en la medida en que como es una sola la relación procesal y sustancial que rige a los sujetos que integran la parte demandante o demandada, la demanda de reconvención deberá formularse por todos los demandados y/o dirigirse contra todos los demandantes ${ }^{50}$.

b. Que sea el mismo juez competente para conocer de la demanda de reconvención y de la demanda original, aunque el mencionado art. 371 establece que se podrá reconvenir sin consideración a la competencia por cuantía ni por factor territorial.

Sin embargo, también es conveniente tener presente que si se presenta demanda de reconvención con pretensiones de mayor cuantía, se produce una alteración de la competencia, y el juez civil municipal que esté conociendo en primera instancia del proceso verbal perderá competencia sobre el asunto y deberá remitir de manera inmediata el expediente al juez civil del circuito para que este continúe con el trámite del proceso, de acuerdo con lo dispuesto en el art. 27 del CGP ${ }^{51}$.

c. Que exista conexidad entre la demanda principal y la demanda en reconvención, en la medida en que, de haberse formulado en proceso separados, hubiera procedido su acumulación.

d. Que las pretensiones de la demanda en reconvención no estén sometidas a trámite especial.

Si el juez admite la demanda en reconvención, este auto se notificará por estado y se dispondrá correrle traslado al demandante por el mismo término de

49 Cfr. Ibídem.

50 Cfr. BEJARANO GUZMÁN, Ramiro, op. cit., p. 29.

51 Inciso 2, art. 27, CGP. Cfr. En el mismo sentido: Cfr. BEJARANO GUZMÁN, Ramiro, op. cit., p. 29. 
la demanda inicial, es decir por veinte días ${ }^{52}$. Sin embargo, debe esperarse a que se venza el término de traslado de la demanda inicial a todos los demandados, para que empiece a correr el término de traslado de la demanda en reconvención, y en lo sucesivo ambas se sustanciarán de manera conjunta y se resolverán en una misma sentencia ${ }^{53}$.

Si el demandado propone excepciones previas y a su vez formula demanda en reconvención, se dará traslado en primer lugar de la demanda en reconvención y luego se dará traslado de las excepciones previas, puesto que, debido a que el demandante se convierte el demandado, el válidamente puede asumir la postura de contestar la demanda, interponer excepciones de fondo, llamar a un tercero e interponer excepciones previas. Si el demandante reconvenido propone a su vez excepciones previas, se establece que estas y las propuestas contra la demanda inicial se decidirán de manera conjunta ${ }^{54}$.

En el mismo sentido, se sugiere por la doctrina que cuando hay demanda en reconvención, contestación con excepciones de mérito y proposición de excepciones previas, el juez se pronuncie primero respecto de la demanda de reconvención y le dé traslado al demandante, y luego de surtido este traslado, si el demandante propone excepciones de mérito y/o previas, estas se puedan tramitar conjuntamente con las propuestas contra la demanda inicial y se pueda correr traslado común ${ }^{55}$.

\subsection{Fase oral}

La fase oral del proceso verbal se desarrollará en audiencias, las cuales, por disposición del CGP, se iniciarán en el primer minuto de la hora hábil señalada pero podrán continuarse en horas inhábiles con habilitación expresa, deberán ser presididas de manera presencial por el juez que conozca del caso so pena de nulidad, se deberán adelantar sin solución de continuidad, para lo cual se deberá reservar el tiempo suficiente para objeto de cada audiencia; y se deberán grabar en medios de audio, audiovisuales o en cualquiera otro que ofrezca seguridad para el registro de lo actuado, dejando constancia de su celebración en un acta que contendrá el nombre de las partes, apoderados, testigos y auxiliares de la

52 Colombia, Congreso de la República, Ley 1564 de 2012, Por medio de la cual se expide el Código General del Proceso, inciso último, art. 371.

53 Colombia, Congreso de la República, Ley 1564 de 2012, Por medio de la cual se expide el Código General del Proceso, inciso 2, art. 371.

54 Colombia, Congreso de la República, Ley 1564 de 2012, Por medio de la cual se expide el Código General del Proceso, inciso 3, art. 371.

55 Cfr. BEJARANO GUZMÁN, Ramiro, op. cit., p. 31. 
justicia, y en dado caso, la parte resolutiva de la sentencia. Se prohíbe además la reproducción escrita por parte del juzgado de las grabaciones de las audiencias y de las intervenciones orales que se hagan en el transcurso de las mismas ${ }^{56}$.

Las audiencias del proceso verbal en el nuevo CGP son dos: i). La audiencia inicial, y ii). La audiencia de instrucción y juzgamiento.

\subsubsection{Audiencia inicial}

Esta audiencia está prevista en el art. 372 del CGP, norma que afirma que el juez deberá señalar hora y fecha para esta audiencia, "lo cual implica la implementación de la regla técnica de la oralidad" ${ }^{57}$; una vez se ha vencido el término de traslado de la demanda, de la reconvención, del llamamiento en garantía, de las excepciones de mérito, de las excepciones previas que deban decidirse antes de audiencia, o realizada la notificación, citación o traslado que el juez ordene al resolver dichas excepciones, según el caso. El auto que fija fecha y hora para la audiencia se notifica por estados y no tiene ningún recurso ${ }^{58}$.

A la audiencia deberán concurrir tanto las partes como sus apoderados. Si alguna de las partes no comparece, sin perjuicio de las consecuencias probatorias que se puedan generar por su inasistencia, la audiencia se llevará a cabo con su apoderado, quien tendrá la facultad para confesar, conciliar, transigir, desistir y, en general, para disponer del derecho en litigio ${ }^{59}$. Sin embargo, surge la duda de que el apoderado judicial esté facultado para conciliar, transigir y disponer de derechos sustanciales de los que no es titular, incluso en perjuicio de su cliente ausente, pues el apoderado judicial al tener derecho de postulación, solamente tiene la facultad general de actuar ante la jurisdicción para defender intereses ajenos, a nombre de su poderdante. Por esta razón, en el art. 70 del C.P.C. se disponía que el apoderado no podía realizar actos que implicaran disposición del derecho en litigo ni los reservados por la ley a la parte misma, salvo que la parte lo hubiera autorizado de manera expresa.

El inciso tercero del art. 77 del CGP señala en su primera parte que: "El poder para actuar en un proceso habilita al apoderado para recibir la notificación del

56 Colombia, Congreso de la República, Ley 1564 de 2012, Por medio de la cual se expide el Código General del Proceso, art. 106; incisos 1 y 3, numeral 1; inciso 1, numeral 2; numeral 4, y numeral 6, art. 107.

57 LÓPEZ BLANCO Hernán Fabio, “Código General Del Proceso, Parte Especial”, cuarta edición, Bogotá, Ed. Dupre Editores Ltda, 2017.

58 Colombia, Congreso de la República, Ley 1564 de 2012, Por medio de la cual se expide el Código General del Proceso, numeral 1, art. 372.

59 Colombia, Congreso de la República, Ley 1564 de 2012, Por medio de la cual se expide el Código General del Proceso, inciso 3, art. 77 y art. 193 
auto admisorio de la demanda o del mandamiento ejecutivo, prestar juramento estimatorio y confesar espontáneamente. Cualquier restricción sobre tales facultades se tendrá por no escrita."

Coordinadamente en cuanto a la confesión por parte del apoderado, menciona la norma, como aquella que se realiza por fuera de la diligencia formal de interrogatorio de parte, y es la manifestación que verse sobre hechos que produzcan consecuencias adversas al confesante y que no necesariamente provienen de las partes pues la ley admite que también ciertas manifestaciones que realice el apoderado pueden conllevar a ese efecto, según lo señala el art. 193 del CGP al indicar que: “ La confesión por apoderado judicial valdrá cuando para hacerla haya recibido autorización de su poderdante, la cual se entiende otorgada para la demanda y las excepciones, las correspondientes contestaciones, la audiencia inicial y la audiencia del proceso verbal sumario. Cualquier estipulación en contrario se tendrá por no escrita."

Esta norma plantea incongruencia con el art. 77 del CGP que no establece limitación a la confesión espontanea, mientras que el art. 193 la acepta para los actos que allí se enlistan taxativamente que si bien es cierto abarcan casi todas las posibilidades de actuación de los apoderados, no las agotan ${ }^{60}$.

En efecto, piénsese en el caso de que el apoderado judicial en el alegato de conclusión realice una confesión espontanea respecto de lo que no tiene autorización expresa de su poderdante, a la luz del art. 193 no se le podría tener como confesión porque no está dentro de las actividades enlistadas, mientras que siguiendo el art. 77, que no establece cualificaciones, si lo seria.

Por ser norma posterior y especial el art. 193, en nuestra opinión esta última norma es la que debe aplicar cuando existan casos de confesión por apoderado judicial.

Frente a lo anterior, la Corte Constitucional admitió una acción pública de inconstitucionalidad en contra de algunos apartes del art. 193 del Código General del Proceso (CGP), el cual define la confesión por apoderado judicial ${ }^{61}$.

El accionante indicó que esta normativa trasgredía los art. $1^{\circ}, 14$ y 29 de la Constitución Política, pues al trasladar la voluntad de confesar de la parte hacia su apoderado se afectaba la dignidad humana, toda vez que esta facultad se

60 NISMIBLAT MURILLO, Nattan; Código General del Proceso, derecho probatorio: introducción a los medios de prueba en particular. Principios y técnicas de oralidad, Ediciones Doctrina y Ley, Bogotá, 2014, p. 338.

61 Colombia, Corte Constitucional, Sala Plena, Auto admisión de acción de inconstitucionalidad, Expediente D- 11304. 
entiende otorgada tácitamente a través del poder conferido y recae sobre hechos personales, personalísimos e incluso íntimos del poderdante.

De igual forma, afirmó que el abogado únicamente tiene una relación contractual con el extremo procesal, desconociendo las circunstancias de tiempo, modo y lugar sobre los hechos para brindar la confesión, por lo que resulta absurdo que sus aseveraciones tengan validez, interfiriendo en el derecho a la intimidad.

El demandante también aseveró que se vulnera el principio de no incriminación, ya que el profesional puede indicar los hechos que inculpan a quien representa y, además, le priva el derecho al debido proceso en atención a las consecuencias que esto puede acarrearle.

Se argumenta que el apoderado se inmiscuye de manera arbitraria, inconsulta y desproporcionada en la intimidad de la parte en un proceso judicial, sea esta persona natural o jurídica ${ }^{62}$. Además, los hechos susceptibles de confesión, en estricto sentido y sana lógica, deben estar reservados exclusivamente a la parte misma que comparece al proceso judicial ${ }^{63}$.

Se hace especialmente grave cuando se dispone que dicha facultad de confesar se entiende extendida al apoderado para la demanda, las correspondientes contestaciones, la audiencia inicial y la del proceso verbal sumario.

Trayendo a colación que una de las manifestaciones concretas de la dignidad humana es el principio de no incriminación y, en el sentido de lo anterior, "en la medida en que la confesión judicial del apoderado puede traer consecuencias adversas a los intereses de la parte que representa, dicha situación implica que en últimas, al permitirse la confesión judicial a través de apoderado, se esté

62 Colombia, Congreso de la República, Ley 1564 de 2012, Por medio de la cual se expide el Código General del Proceso. Artículo 195. Declaraciones de los representantes de personas jurídicas de derecho público. No valdrá la confesión de los representantes de las entidades públicas cualquiera que sea el orden al que pertenezcan o el régimen jurídico al que estén sometidas.

Sin embargo, podrá pedirse que el representante administrativo de la entidad rinda informe escrito bajo juramento, sobre los hechos debatidos que a ella conciernan, determinados en la solicitud. El juez ordenará rendir informe dentro del término que señale, con la advertencia de que, si no se remite en oportunidad sin motivo justificado o no se rinde en forma explícita, se impondrá al responsable una multa de cinco (5) a diez (10) salarios mínimos mensuales legales vigentes (smlmv)."

63 BOHÓRQUEZ, Ángel María, De la confesión como prueba en juicio, tesis elaborada y sostenida para optar por el título de Doctor en derecho; Universidad Nacional, Facultad de Derecho y Ciencias Políticas; Imprenta Bohórquez, Bogotá: 1918 En http://www. banrepcultural.org/blaavirtual/derecho/de-la-confesion-como-prueba-en-juicio. Consultado el 27/02/2017. 
vulnerando el principio de la no incriminación de la parte litigante, toda vez que su apoderado puede confesar, por acción o por omisión, hechos que terminen incriminando a la parte que representa".

Considerando que la personalidad jurídica prevista en el art. 14 de la Constitución Política no solo es la capacidad de contraer obligaciones y ejercer derechos, sino que, adicionalmente comporta un ser humano dotado de atributos de la personalidad, por tanto, se desconoce que toda persona es única, irrepetible e intransmisible y que, por tanto, goza de autonomía y voluntad; lo que hace imposible que un sujeto diferente como es su apoderado, confiese en su nombre y representación.

Se aduce que se trasgrede igualmente el art. 29 de la Constitución Política, toda vez que está privando a la parte que otorga el poder de la garantía constitucional, en atención a las trascendentales consecuencias procesales que una confesión judicial de un apoderado pueda acarrearle a sus derechos o intereses. Que el art. 77 del CGP establece que la confesión debe ser autorizada expresamente y que permitir lo contrario es disponer del derecho del poderdante de manera tácita, máxime si la misma norma informa que cualquier estipulación en contrario (sobre el efecto dado por el hecho de otorgar poder y su facultad para confesar en tales momentos procesales), se debe tener por no escrita.

Respecto de esto último se precisa que el art. 193 del CGP le impide a la parte que otorga el poder, reservarse para sí misma la facultad de confesar, en atención a que la parte final del mismo expresamente consagra que cualquier estipulación en contrario se tendrá por no escrita, lo cual se constituye en una injerencia arbitraria en la voluntad de la parte por parte del legislador colombiano, en tanto se le está afectando de manera directa el Derecho al Debido Proceso, en tanto la norma en mención, está privando a la parte de la facultad de confesar, para, en su lugar, otorgársela incondicionadamente al apoderado que la está representando. Y esta situación conlleva, de facto, a que en el apoderado esté radicada la facultad de disponer del derecho en litigio, agravándose de esta manera el Derecho al Debido Proceso que le asiste a la parte.

Sin embargo, la Corte Constitucional consideró que el artículo 193 del CGP era exequible pues contribuye a la buena y eficaz administración de justicia e impone una carga de responsabilidad a los abogados sobre las afirmaciones y negaciones que realizan en los procesos judiciales ${ }^{64}$.

De otra parte, si los apoderados no concurren a la audiencia inicial, se establece por el CGP que esta se desarrollará con las partes.

64 Cfr. Colombia, Corte Constitucional, Sentencia C-551 de 2016, Magistrado Ponente: Jorge Iván Palacio. 
Sin embargo, tanto las partes como sus apoderados se pueden excusar por no asistir a la audiencia inicial. Dicha excusa puede ser antecedente o posterior. $\mathrm{Si}$ la excusa es anterior a la fecha de celebración de la audiencia, sólo podrá justificarse mediante prueba siquiera sumaria de una justa causa. Si el juez acepta la justificación, se fijará nueva fecha y hora para la celebración de la audiencia mediante auto que no es susceptible de ningún recurso, y la nueva audiencia deberá celebrarse dentro de los 10 días siguientes, sin posibilidad de que haya otro aplazamiento.

En tratándose de la excusa posterior a la audiencia, esta sólo se apreciará por el juez si se aporta dentro de los 3 días siguientes a la celebración de la audiencia, y si está fundamentada en fuerza mayor o caso fortuito; y sólo tendrá el efecto de exonerar de las consecuencias procesales, probatorias y pecuniarias que se deriven de la inasistencia. En esta hipótesis, si el juez acepta la excusa, prevendrá a la parte que la presentó para que concurra a la audiencia de instrucción y juzgamiento a absolver el interrogatorio de parte. Esto se prevé de esta forma por el Código, debido a que el interrogatorio de parte es una prueba obligatoria, oficiosa y exhaustiva.

Por el contrario, la inasistencia injustificada del demandante hará presumir como ciertos los hechos en que se fundan las excepciones propuestas por el demandado siempre que sean susceptibles de confesión; y la inasistencia del demandado hará presumir como ciertos los hechos susceptibles de confesión en que se funde la demanda. Si ninguna de las partes concurre a la audiencia y no presentan justificación ni antecedente ni posterior de este hecho, el juez declarará terminado el proceso, y no se entenderá interrumpida la prescripción o inoperante la caducidad con la presentación de la demanda ${ }^{65}$.

Además de las consecuencias procesales y probatorias, las partes y los apoderados que no concurran injustificadamente a la audiencia se harán acreedores de una multa de 5 SMLMV.

El art. 106 del CGP señala en el inciso primero que las "audiencias y diligencias judiciales se adelantaran en días y horas hábiles, sin perjuicio de los casos en que la ley o el juez dispongan de realizarlos en horas inhábiles", para sentar como regla general que será en días laborales y dentro del horario señalado para el respectivo despacho judicial, que no necesariamente tiene que ser igual en todo el país, que se debe fijar la fecha y hora de iniciación, lo que no es obstáculo para que en casos excepcionales el juez puede fijar un día inhábil, ejemplo un domingo, o en un día hábil pero en hora fuera del despacho como seria, por ejemplo, a las 10 p.m., si por índole especial de la prueba a recepcionar o la

65 Colombia, Congreso de la República, Ley 1564 de 2012, Por medio de la cual se expide el Código General del Proceso, numeral 7, art. 95. 
diligencia a practicar se impone especial fijación y respecto de la cual se estima el juez debe motivar sucintamente el porqué de esa decisión.

Como es frecuente que la audiencia o diligencia se señala en día y hora hábil, pero que se dilate de la práctica de ella a una hora inhábil, puede el juez proseguir en su desarrollo sin necesidad de "habilitación expresa", según el inciso segundo del art. 106, con lo que se expide carta de defunción a la costumbre de que en tal hipótesis era menester que el juez expresamente habilitara la hora judicial, so pena de ineficacia de lo citado a partir del momento en que la hora paso a ser inhábil.

En resumen, iniciada la audiencia o diligencia en hora hábil puede seguir la actuación para tratar de agotar la misma y, salvo motivos especiales, pero jamás por el hecho de llegar por ejemplo las 6 p.m., podrá el juez suspender su trámite.

El art. 107 del CGP en el inciso tercero del numeral primero dispone: "las audiencias y diligencias, se iniciarán en el primer minuto de la hora señala para ellas, aun cuando ninguna de las partes o sus apoderados se hallen presentes", lo que implica que la iniciación del acto judicial para la cual se ha fijado la respectiva hora deberá hacerse dentro de los sesenta minutos que la integran, esto es, que si una audiencia o diligencia se ha señalado para las 10 de la mañana, debe dársele comienzo antes que venza la hora judicial, es decir antes de las once.

Infortunadamente, el concepto de la hora judicial había sido malinterpretado tanto por los jueces como los abogados ${ }^{66}$ debido a que algunos estimaron que la diligencia no se podría realizar sino hasta segundos antes del vencimiento de la hora señalada. En absoluto, si señala una hora judicial, lo lógico, lo legal y lo correcto es que la diligencia se inicie al empezar la correspondiente hora y no cuando está a punto de culminar; de ahí que se observa con sorpresa algunas circunstancias de ciertos abogados que llegan al despacho pasados 45 minutos de comenzada la hora judicial, y encuentran que la diligencia ya empezó o, inclusive, que terminó, alegan para excusar supuesta parcialidad o incumplimiento de los deberes del juez, en los que han debido esperar hasta antes de vencer los respectivos sesenta minutos.

Si las partes o sus apoderados han concurrido a la audiencia, esta se iniciará, se instalará y en ella se desarrollarán los siguientes actos procesales:

1. Decisión de excepciones previas: En esta etapa procesal el juez practicará las pruebas que decretó como necesarias para resolver las excepciones previas pendientes $^{67}$, y luego las decidirá.

66 Cfr., 5 Ibídem.

67 Se considera que las excepciones previas pendientes no pueden ser otras que la falta de integración del litisconsorcio necesario y la falta de competencia por la persona natural o 
2. Conciliación judicial entre las partes: Desde el inicio de la audiencia y en cualquier etapa de ella, el juez está facultado para exhortar de manera diligente a las partes a conciliar sus diferencias, para lo cual deberá proponer fórmulas de arreglo, sin que ello constituya prejuzgamiento.

Cuando una de las partes esté representada por curador ad litem, el curador debe concurrir a la audiencia so pena de sanciones pecuniarias que le podrá imponer el juez, pero para efectos distintos de la conciliación y de la admisión de hechos perjudiciales a aquella, puesto que el curador ad litem no puede confesar.

3. Interrogatorio de parte: Los interrogatorios de parte se practican en esta audiencia, y el juez también interrogará de modo exhaustivo a las partes sobre el objeto del proceso, y podrá ordenar el careo entre ellas. El interrogatorio de parte es uno de los pocos casos, dentro del principio dispositivo que rige los procesos civiles, en los cuales se debe decretar de oficio un medio de prueba.

De otra parte, una duda que surge respecto a esta disposición es ¿Qué valor probatorio tienen los careos entre las partes? Es claro que estos hechos, atendiendo al principio de inmediación y de oralidad, influyen en la subjetividad del juez y en la manera cómo percibe las hipótesis fácticas del caso, sin embargo, no es claro y la norma no establece si los careos tienen un valor probatorio independiente o hacen parte integrante del interrogatorio de parte, pues las partes no pueden constituir su propia prueba a partir de afirmaciones que hagan.

El careo procesal no es nuevo dentro del ordenamiento jurídico colombiano, e incluso tiene su origen en los careos que podía promover el funcionario penal en la fase de investigación, entre los testigos y el procesado cuando hubiese versiones contradictorias.

Así entonces, la Ley 94 de 1938, que consagró uno de los primeros Códigos de Procedimiento Penal, afirmaba que el funcionario competente en la fase de instrucción tenía la potestad de promover careos entre los testigos y los

por el lugar de ocurrencia de los hechos, que son las dos únicas que necesitarán máximo dos testimonios para su reconocimiento y declaratoria, adicional a las pruebas que se encuentren presentes en el expediente, so pena de la facultad que tendría el juez para decretar pruebas de oficio. Estos testimonios serían los que se deberán decretar antes de la audiencia inicial, para que se puedan practicar al inicio de ella y se puedan decidir sobre estas excepciones previas pendientes. Cfr. En el mismo sentido: TEJEIRO DUQUE, Octavio, "Los procesos declarativos y el desarrollo de la audiencia”, En: Código General del Proceso comentado, Bogotá, 2014, Instituto Colombiano de Derecho Procesal (ICDP), pp. 347-360, p. 353. 
procesados entre sí o entre aquéllos y estos cuando sus versiones sobre los hechos fueran contradictorias, y los hacía comparecer y exhortaba a decir la verdad unos frente a los otros, sin que tuvieran oportunidad de leer sus declaraciones anteriores ${ }^{68}$.

Con posterioridad, se profiere el decreto 409 de 1971, decreto reformatorio al Código de Procedimiento Penal de 1938, en el cual se establecen también los careos procesales en la fase investigativa entre los testigos o entre los procesados y entre aquéllos y estos, de la misma manera que en el Código Procesal Penal del $38^{69}$.

La figura de los careos procesales se traspasa luego al ordenamiento procesal civil, y el C.P.C. estableció en su art. 230 que, en el marco de la práctica de la prueba testimonial, el juez podía ordenar, de oficio, y cuando lo considerara conveniente, el careo de los testigos entre sí y de éstos con las partes ${ }^{70}$. Sin embargo, esta figura se derogó expresamente por el CGP a partir de la fecha en que entrara a regir de forma integral, y, por el contrario, como se

68 Colombia, Congreso de la República, Ley 94 de 1938: art. 376: “Cuando los testigos o procesados entre sí, o aquéllos con éstos discordaren acerca de algún hecho o de alguna circunstancia que interesen a la investigación, el funcionario podrá ordenar el careo de los discordantes. El careo debe hacerse sólo entre dos personas". Art. 377: "Para verificar el careo el funcionario hará comparecer a las personas cuya declaración sea contradictoria, juramentará a los que sean testigos y exhortará a todos a decir la verdad; sin leer a los careados sus declaraciones, hará que éstos declaren de nuevo en presencia el uno del otro y en el orden que el Juez considere oportuno. En seguida, el funcionario ordenará que cada uno de los careados haga al otro las preguntas que estimare conducentes y las observaciones a que dieren lugar".

69 Colombia, Decreto 409 de 1971: art. 413: “<Decreto derogado por el artículo 678 del Decreto 50 de 1987> Cuando los testigos o procesados entre sí, o aquéllos con éstos discordaren acerca de algún hecho o de alguna circunstancia que interese a la investigación, el funcionario podrá ordenar el careo de los discordantes. El careo debe hacerse solo entre dos personas". Art. 414: "Procedimiento para el careo. <Decreto derogado por el artículo 678 del Decreto 50 de 1987> Para verificar el careo el funcionario hará comparecer a las personas cuyas declaraciones sean contradictorias, juramentará a los que sean testigos y exhortará a todos a decir la verdad; sin leer a los careados sus declaraciones, hará que éstos declaren de nuevo en presencia el uno del otro y en el orden en que el juez considere oportuno. En seguida, el funcionario ordenará que cada uno de los careados haga al otro las preguntas que estimare conducentes y las observaciones a que diere lugar y procederá luego a interrogarlos".

70 Art. 230, CPC: "Careos. <Artículo derogado por el literal c) del artículo 626 de la Ley 1564 de 2012. Rige a partir del 1o. de enero de 2014, en forma gradual, en los términos del numeral 6) del artículo 627>El juez podrá ordenar, cuando lo considere conveniente, careos de los testigos entre sí y de éstos con las partes, en las oportunidades indicadas en el artículo 180". El Art. 180 de este mismo estatuto procesal se refería a la prueba de oficio. 
mencionó en párrafos anteriores, se estableció el careo entre las partes en el interrogatorio de parte.

De igual forma, el careo procesal desapareció, en materia penal de los posteriores códigos de procedimiento penal (Ley 600 de 2000, y Ley 906 de 2004). Sin embargo, la sala penal de la Corte Suprema de justicia se pronunció en relación con el valor probatorio del careo procesal, afirmando, en primer lugar, que el careo presupone la comparecencia simultánea de las personas cuyas versiones son contradictorias, y al llevarlo a cabo deben preservarse todas las formalidades, el debido proceso y las garantías sustanciales inherentes a la posición que cada sujeto ocupe dentro del proceso. Además, a juicio de la Corte, el careo aunque es un medio probatorio, no está regulado de manera autónoma en el Derecho Procesal Penal, por lo que el juez deberá valorarlo conforme a la sana crítica y guiándose por regulaciones de medios probatorios correlacionados, tales como el interrogatorio de parte o indagatoria $\mathrm{o}$ el testimonio, según cada caso $^{71}$.

En este sentido, si uno extrapolara estas afirmaciones dadas por la sala penal de la Corte Suprema de Justicia a la valoración de los careos dentro del interrogatorio de parte en el proceso verbal del CGP, tendría que afirmar que las afirmaciones que se produzcan en el marco de dichos careos deberán ser parte integrante del interrogatorio de parte, valorándose por el juez de acuerdo a las normas que lo regulan, de acuerdo a su sana crítica y en conjunto con los demás medios de prueba, para afirmar que si en dichos careos las partes dicen algo que los desfavorezca o favorezca a la contraparte, dichas afirmaciones deberán valorarse como confesiones, o en caso contrario, deberán valorarse como simples declaraciones de parte.

4. Fijación del litigio: A continuación, el juez requerirá a las partes y a sus apoderados para que determinen los hechos en los que están de acuerdo y que fueren susceptibles de prueba de confesión, y fijará el objeto del litigio, precisando los hechos que se consideran demostrados y los que requieran ser probados. El juzgador al momento del decreto de las pruebas, deberá prescindir de los medios probatorios que estén dirigidos a acreditar los hechos que se aceptaron como probados por las partes en esta fase de la fijación del litigio.

5. Control de legalidad o saneamiento del proceso: El juez debe ejercer un control de legalidad de todos los actos procesales que se hayan surtido y sanear los vicios que puedan acarrear nulidades $\mathrm{u}$ otras irregularidades procesales, para asegurar el pronunciamiento de una sentencia de fondo. Además, se

71 Cfr. Colombia, Corte Suprema de Justicia, sala de Casación Penal, sentencia del 9 de noviembre de 2006, Magistrado Ponente: Javier Zapata Ortiz, Exp: 2006-23775. 
deberá verificar la integración del litisconsorcio necesario, cuando en el caso concreto se presente por razones sustanciales o legales.

6. Decreto de pruebas: El juez decretará, a través de auto, todas las pruebas aportadas y solicitadas por las partes y las que de oficio considere necesarias para el esclarecimiento de los hechos objeto del proceso. $\mathrm{Si}$, en casos excepcionales, decreta la práctica de un dictamen pericial, en este auto se deberá señalar el término para que se aporte, teniendo en cuenta que deberá presentarse con no menos de 10 días de antelación a la audiencia de instrucción y juzgamiento.

En los procesos en los que sea obligatorio practicar inspección judicial ${ }^{72}$, el juez deberá fijar fecha y hora para practicarla antes de la audiencia de instrucción y juzgamiento.

7. Fijación de la audiencia de instrucción y juzgamiento: si el juez advierte que es posible y conveniente practicar las pruebas en la audiencia inicial, de oficio o a petición de parte, decretará las pruebas en el auto que fija fecha y hora para la audiencia inicial, con el fin de agotar también el objeto de la audiencia de instrucción y juzgamiento de que trata del art. 373 del CGP, y en una única audiencia se proferirá la sentencia ${ }^{73}$.

De otra parte, si el proceso es de aquellos casos fáciles o de aquéllos que no requiere práctica de pruebas, al finalizar el control de legalidad, se oirán los alegatos de conclusión de 20 minutos de las partes, y se dictará sentencia anticipada.

Y finalmente, si ninguna de estas dos hipótesis se cumple, el juez, antes de finalizar la audiencia inicial, fijará fecha y hora para la audiencia de instrucción y juzgamiento, audiencia en la cual se practicarán todas las pruebas decretadas.

Partiendo del hecho de que se permite que la audiencia inicial se lleve a cabo sin la presencia de las partes, so pena de que presenten justa causa de inasistencia, surge la duda de qué pasaría si el juez cree posible y conveniente llevar a cabo en una sola audiencia todas las actuaciones procesales de la audiencia inicial y de la

72 En los únicos procesos verbales en los cuales es obligatoria la práctica de la inspección judicial es en aquellos con disposiciones especiales, como la declaración de pertenencia y el proceso de sucesiones.

73 En un mismo sentido se pronuncia la doctrina al afirmar que existe la posibilidad de realizar una o dos audiencias (inicial y/o de instrucción y juzgamiento) de acuerdo con la complejidad del caso, y ésta sólo es una decisión del juez, que obedece a lo indicado por el numeral 1 del art. 42 del CGP, en cuanto le impone la obligación de velar por la rápida solución del proceso y procurar la mayor economía procesal. Cfr. TEJEIRO DUQUE, Octavio, op. cit., pp. 349-350. 
audiencia de instrucción y juzgamiento y proferir el fallo allí mismo, y una de las partes no asiste a dicha audiencia y se excusa con posterioridad a ella cuando ya se ha proferido el fallo.

No se podría afirmar que la sentencia es nula, puesto que todas las actuaciones procesales dentro de la audiencia fueron completamente válidas e incluso se notificaron por estrados aún sin la presencia de dicha parte. Sin embargo, si se considera que en este evento por cuestiones de fuerza mayor o caso fortuito la parte ausente no tuvo la oportunidad de ejercer de una manera eficaz su derecho de defensa y contradicción dentro del proceso, y no tuvo opción de absolver el interrogatorio de parte, pues el apoderado judicial no puede absolverlo él solo, aunque se presuma que puede confesarse por el cliente, porque esta última hipótesis de confesión es espontánea y no provocada.

Por esta razón, se considera que en este evento el juez debería instalar la audiencia, pero suspenderla antes de emitir el fallo y esperar los tres días de plazo que posee la parte ausente para presentar una excusa justificada de su inasistencia, aún en contravía de la prohibición que establece el art. 5 del CGP, de no aplazar ni suspender las audiencias y diligencias, pues los artículos 11 y 12 de este estatuto procesal establecen que al interpretar y aplicar la ley procesal el juez debe tener en cuenta la efectividad de los derechos sustanciales de los intervinientes en el proceso, los principios constitucionales, los derechos fundamentales, el debido proceso, y el derecho de defensa; y debe determinar la forma de realizar los actos procesales procurando hacer efectivo el derecho sustancial y los principios constitucionales ${ }^{74}$.

\subsubsection{Audiencia de instrucción y juzgamiento y sentencia}

Una vez se haya fijado mediante auto la fecha y hora para la celebración de la audiencia de instrucción y juzgamiento, el art. 373 del CGP establece que el juez deberá disponer de tiempo suficiente para practicar todas las pruebas decretadas, oír los alegatos de las partes, y proferir la sentencia.

$74 \quad$ Art. 11, CGP: "Al interpretar la ley procesal el juez deberá tener en cuenta que el objeto de los procedimientos es la efectividad de los derechos reconocidos por la ley sustancial. Las dudas que surjan en la interpretación de las normas del presente código deberán aclararse mediante la aplicación de los principios constitucionales y generales del derecho procesal garantizando en todo caso el debido proceso, el derecho de defensa, la igualdad de las partes y los demás derechos constitucionales fundamentales. El juez se abstendrá de exigir y de cumplir formalidades innecesarias". Art. 12, CGP: "Cualquier vacío en las disposiciones del presente código se llenará con las normas que regulen casos análogos. A falta de éstas, el juez determinará la forma de realizar los actos procesales con observancia de los principios constitucionales y los generales del derecho procesal, procurando hacer efectivo el derecho sustancial". En el mismo sentido: TEJEIRO DUQUE Octavio, op. cit., p. 351. 
Si alguna de las partes justificó su inasistencia a la audiencia inicial, se practicará el interrogatorio a la respectiva parte. En seguida, el juez requerirá a las partes y a sus apoderados para que determinen los hechos en los que están de acuerdo y que fueren susceptibles de prueba de confesión, fijará nuevamente el litigio, precisando los hechos que considera demostrados y rechazará las pruebas decretadas en la audiencia inicial que estime innecesarias. Esta disposición se considera criticable en la medida en que el filtro de la fijación del objeto del litigio y de la utilidad, pertinencia, conducencia y licitud de la prueba ya se debió haber surtido en la audiencia inicial con el auto que decretó las pruebas. Proponer que se vuelva a realizar este análisis en la audiencia de instrucción y juzgamiento va en contra de los principios de economía y celeridad procesal.

La única hipótesis en la que se consideraría posible que el juez fije nuevamente el litigio en la audiencia de instrucción y juzgamiento es cuando existe excusa justificada de alguna de las partes y debe practicarse el interrogatorio de parte, pues el juez, de acuerdo con lo que diga dicha parte, podría volver a delimitar el objeto de prueba en el respectivo proceso y hacerse a la idea de un nuevo panorama fáctico, que lo conduciría a tener que fijar nuevamente el litigio.

A continuación, si no hubo necesidad de practicar el interrogatorio de parte pendiente o practicado este, el juez practicará los demás medios de prueba en el siguiente orden:

1. Practicará el interrogatorio a los peritos que hayan sido citados a la audiencia, de oficio o a solicitud de parte ${ }^{75}$.

2. Recibirá las declaraciones de los testigos que se encuentren presentes y en relación con los testigos ausentes prescindirá de ellos.

3. Practicará la exhibición de documentos, si se hubiese pedido, y las demás pruebas que hubieren sido decretadas.

Practicados todos los medios de prueba, el juez oirá los alegatos de conclusión de las partes, escuchando en primer lugar al demandante, luego al demandado y finalmente a las demás partes que intervinieron en el proceso, hasta por 20 minutos cada uno. Sin embargo, por solicitud de alguna de las partes, el fallador, mediante auto que no será susceptible de recurso alguno, podrá autorizar un tiempo superior para rendir las alegaciones, atendiendo

75 Con el CGP, la regla general es que el dictamen pericial sea de parte, y para que sea controvertido la contraparte puede allegar un nuevo dictamen pericial o solicitar en la audiencia inicial que el perito asista a la audiencia de instrucción y juzgamiento para ser interrogado. En esta última hipótesis, el art. 228 del CGP afirma que si el perito citado no asiste a la audiencia de instrucción y juzgamiento, el dictamen no tendrá ningún valor. 
a las circunstancias particulares y de complejidad del caso y garantizando la igualdad $^{76}$.

Finalmente, y luego de escuchados los alegatos de conclusión, en esta misma audiencia de instrucción y juzgamiento, el juez deberá proferir sentencia que resuelva el litigio de manera oral, aunque las partes o sus apoderados no hayan asistido o se hubieran retirado, y esta sentencia se notificará por estrados ${ }^{77}$. $\mathrm{Si}$ fuera necesario, el fallador podrá decretar un receso hasta de 2 horas para el pronunciamiento de la sentencia. En la nueva dinámica de los procesos orales, y en específico con el nuevo proceso oral que trae el CGP, proferir la sentencia de forma verbal por parte de los jueces es la regla general y la posibilidad de proferirla por escrito sólo se producirá en casos excepcionales.

Si no le fuera posible al juez dictar la sentencia en forma oral, el art. 373 del CGP afirma que aquél deberá dejar constancia expresa de las razones concretas por las cuales no pudo emitir el fallo, deberá informar a la Sala Administrativa del actual Consejo Superior de la Judicatura, deberá anunciar el sentido de la sentencia con una breve exposición de sus fundamentos, y finalmente deberá emitir el fallo escrito dentro de los 10 días siguientes a la fecha de celebración de la audiencia, sin que en ningún caso se pueda desconocer el término general de duración del proceso, previsto en el art. 121 del CGP.

Si la sentencia se profiere de forma oral, se entenderá notificada en estrados y la apelación deberá interponerse por la parte afectada de manera oral e inmediata, conforme lo establece el inciso 1 del numeral 1 del art. 322 del CGP. Por el contrario, si la sentencia se profiere finalmente por escrito, el fallo se notificará por estado ${ }^{78}$, y la apelación por la parte inconforme deberá interponerse por escrito dentro de los 3 días siguientes a su notificación por estado, de acuerdo con lo previsto en el inciso 2 del numeral 1 del art. 322 del CGP.

Finalmente, el proceso verbal mencionado en el Código General del Proceso y abordado con detalla en este texto, se puede describir gráficamente de la siguiente manera:

76 Colombia, Congreso de la República, Ley 1564 de 2012, Por medio de la cual se expide el Código General del Proceso, art. 11.

77 Colombia, Congreso de la República, Ley 1564 de 2012, Por medio de la cual se expide el Código General del Proceso, art.294, CGP.

78 Colombia, Congreso de la República, Ley 1564 de 2012, Por medio de la cual se expide el Código General del Proceso, art.295, CGP. 


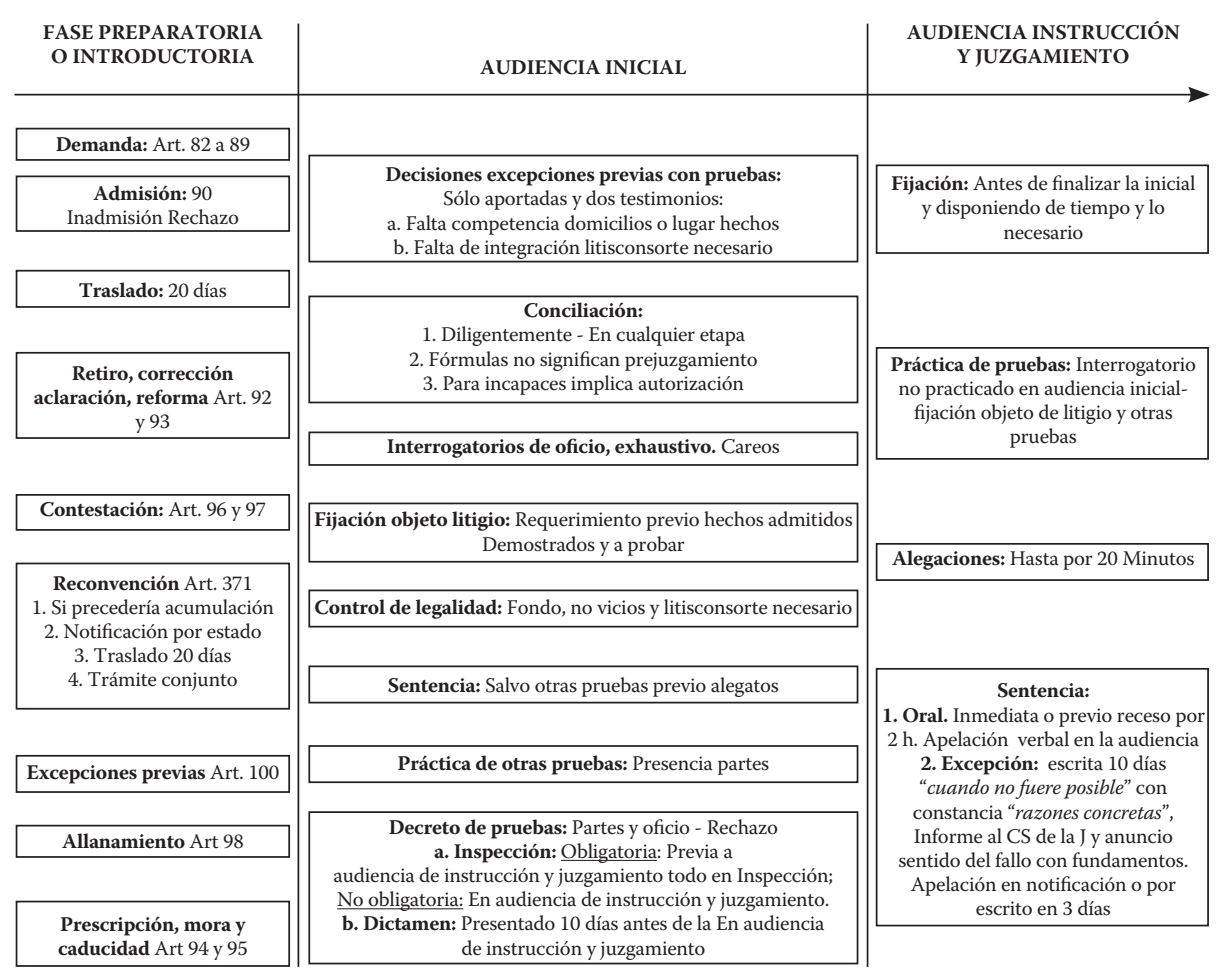

Gráfico tomado de: CANOSA SUÁREZ, Ulises, "Novedades pruebas en el Código General del Proceso", Universidad Nacional de Colombia, Auditorio Camilo Torres, Bogotá, 2017.

\section{Consideraciones Finales}

De las normas anteriormente analizadas, se deduce que el CGP pretende que los procesos civiles, y de forma específica el proceso verbal, sea un proceso célere, donde opere la concentración de actuaciones procesales, donde todos los actos, solicitudes y peticiones de las partes y cuestiones jurídicas se resuelvan de manera oral con la presencia del juez, "garantizando una tutela judicial efectiva con duración razonable"79 y en donde el juez disponga de todos los elementos necesarios para poder producir un fallo de fondo y motivado desde el punto de vista fáctico y jurídico, pues ha tenido un contacto permanente con las partes y con la práctica de los diversos medios probatorios que se allegaron al expediente.

Además, estas pretensiones se refuerzan con la obligación de los jueces de tramitar todos los procesos durante el término máximo de 1 año, so pena de que 79 LÓPEZ BLANCO, Hernán Fabio, Código General del Proceso, Parte Especial, cuarta
edición, Bogotá, Ed. Dupre Editores Ltda, 2017.

184 Revista del Instituto Colombiano de Derecho Procesal • No. 45 
pierdan la competencia para seguir conociendo del asunto y de que sean desfavorablemente calificados en su evaluación de desempeño; y con la aplicación práctica de principios como el de la lealtad procesal, que se traduce en un deber de las partes y apoderados de colaborar con el desarrollo del proceso, enviando a las demás partes vía correo electrónico un ejemplar de los memoriales que se presenten en el proceso a más tardar al día siguiente a la presentación del memorial, so pena de ser acreedores de sanciones pecuniarias (multas).

Respecto al término de duración del proceso, el art. 121 del CGP establece que, salvo interrupción o suspensión del proceso por causas legales, no podrá transcurrir un lapso superior a 1 año para dictar sentencia de primera o de única instancia, contado a partir de la notificación del auto admisorio de la demanda a la parte demandada. Sin embargo, si el juez dentro de los 30 días siguientes a la presentación de la demanda no notifica al demandante del auto admisorio de la misma, este término se contará a partir del día siguiente a la fecha de presentación de la demanda, como una sanción al juez por su falta de diligencia al expedir el auto admisorio de la demanda en un término perentorio ${ }^{80}$.

Del mismo modo, el plazo para resolver el litigio y agotar el proceso en la segunda instancia no podrá ser superior a 6 meses, contados a partir de la recepción del expediente en la secretaría del juzgado o Tribunal.

Si este término vence sin haberse dictado la sentencia correspondiente por el juez, el funcionario perderá automáticamente competencia para conocer del proceso, por lo cual, al día siguiente deberá informar de esta situación a la Sala Administrativa del actual Consejo Superior de la Judicatura y remitir el expediente al juez o magistrado que le sigue en turno, de manera directa, y sin necesidad de reparto ni de participación de las oficinas de apoyo judicial, y este asumirá competencia y deberá proferir el fallo dentro de un término máximo de 6 meses. Además, el vencimiento de estos términos y la pérdida de competencia del juez, deberá ser tenida en cuenta como criterio obligatorio de calificación de su desempeño.

Finalmente, respecto del deber que poseen las partes dentro del proceso de enviar los memoriales a las demás partes después de radicados, el art. 78 del CGP prescribe que se debe enviar una copia de los mismos por correo electrónico a más tardar el día siguiente a su radicación, y el incumplimiento de este deber no afecta la validez de la actuación, pero las demás partes afectadas podrán solicitar al juez la imposición de una multa hasta por 1 SMLMV por cada infracción ${ }^{81}$.

80 Colombia, Congreso de la República, Ley 1564 de 2012, Por medio de la cual se expide el Código General del Proceso, inciso 3, numeral 7, art. 90.

81 Colombia, Congreso de la República, Ley 1564 de 2012, Por medio de la cual se expide el Código General del Proceso, numeral 14, Art. 78, CGP. 
Aunque esta norma debe ser resaltada por la intención que tuvo el legislador de fortalecer el principio de lealtad procesal dentro del proceso civil, se considera que el legislador realizó una interpretación exagerada y al extremo de este principio, pues si bien es cierto que este implica colaborar con el desarrollo y el transcurso de los procesos judiciales, no realizar actos deshonestos o de mala fe que perjudiquen a la contraparte, no utilizar la propia culpa o negligencia en beneficio propio para obtener de allí consecuencias procesales favorables, no es menos cierto que cada una de las partes o de los apoderados debe tener la carga de revisar los procesos judiciales y de revisar los expedientes para enterarse de las últimas actuaciones que se hayan presentado o surtido. No es contrario a la buena fe radicar memoriales sin que la contraparte sepa desde un inicio de ellos, pues esto hace parte de la estrategia procesal ejercida dentro de los límites de la ley, y no se violaría per se el derecho de defensa ni el debido proceso de la contraparte, pues se prevén otros mecanismos en el CGP para garantizar estos derechos, como el traslado y las notificaciones.

\section{Bibliografía}

BEJARANO GUZMÁN Ramiro, Procesos declarativos, arbitrales y ejecutivos, Sexta Edición, Bogotá, Ed. Temis, año 2016.

BOHÓRQUEZ, Ángel María, De la confesión como prueba en juicio, tesis elaborada y sostenida para optar por el título de Doctor en derecho, Universidad Nacional, Facultad de Derecho y Ciencias Políticas, Imprenta Bohórquez, Bogotá, 1918. En: http://www.banrepcultural.org/blaavirtual/derecho/de-laconfesion-como-prueba-en-juicio. Consultado el 27/02/2017

Colombia, Congreso de la República, Ley 1564 de 2012, Por medio de la cual se expide el Código General del Proceso.

Colombia, Congreso de la República, Ley 1395 de 2010, ley de descongestión judicial.

Colombia, Gobierno Nacional, Decreto Nacional 1400 de 1970, Código de Procedimiento Civil.

Colombia, Congreso de la República, Ley 527 de 1999, ley sobre mensajes de datos y comercio electrónico.

Colombia, Gobierno Nacional, Decreto 333 de 2014, mediante el cual se reglamenta la Ley 527 de 1999 sobre mensajes de datos y comercio electrónico.

Colombia, Gobierno Nacional, Decreto Nacional 2364 de 2012, por medio del cual se reglamenta el artículo 7 de la Ley 527 de 1999, ley sobre mensajes de datos y comercio electrónico. 
Colombia, Congreso de la República, Ley 640 de 2001, mediante la cual se regula la conciliación.

Colombia, Congreso de la República, Ley 94 de 1938 (Primer Código de Procedimiento penal).

Colombia, Gobierno Nacional, Decreto 409 de 1971, por medio del cual se reforma la Ley 94 de 1938 (Primer Código de Procedimiento Penal).

Colombia, Corte Suprema de Justicia, Sala de Casación penal, Magistrado Ponente: Javier Zapata Ortiz, sentencia del 9 de noviembre de 2006, Exp: 2006-23775.

DEVIS HECHANDIA, Hernando, Estudios de Derecho Procesal, Bogotá, Ed. ABC, 1979.

FLÓREZ, Germán Darío, "La validez jurídica de los documentos electrónicos en Colombia a partir de su evolución legislativa y jurisprudencial”, Revista Verba Iuris No. 31, enero-junio de 2014, Bogotá D.C, Colombia, ISSN: 0121-3474, (pp. 43-71), Disponible en: http://www.unilibre.edu.co/verbaiuris/31/la-validez-juridica-de-los-documentos-electronicos-en-colombia-a-partir-de-su-evolucion-legislativa-y-jurisprudencial.pdf, fecha de consulta: 17 de junio de 2016.

LÓPEZ BLANCO, Hernán Fabio, Lay 1395 de 2010, Reformas al Código de Procedimiento Civil, Dupre Editores, Bogotá, 2010.

LÓPEZ BLANCO, Hernán Fabio, Código General Del Proceso, Parte General, cuarta edición, Bogotá D.C, Colombia, Ed. Dupre Editores Ltda, 2016.

NISMIBLAT MURILlO, Nattan, Código General del Proceso, derecho probatorio: introducción a los medios de prueba en particular. Principios y técnicas de oralidad, Ediciones Doctrina y Ley, Bogotá, 2014.

PARRA QUIJANO, Jairo, Manual de derecho probatorio, 7 ed., Santa Fe de Bogotá, Ediciones Librería del Profesional, 1997.

Colombia. Corte Constitucional, Sala Plena, Auto admisión de acción de inconstitucionalidad, Expediente D- 11304.

ROJAS GÓMEZ, Miguel Enrique, El proceso civil colombiano, cuarta edición, Bogotá D.C, Colombia, Ed. Universidad Externado, 2011.

TEJEIRO DUQUE, Octavio, "Los procesos declarativos y el desarrollo de la audiencia”, En: Código General del Proceso comentado, año 2014, Bogotá, Instituto Colombiano de Derecho Procesal, pp. 347-360. 